\title{
The Development of Seni Silat Melayu in Kota Bharu, 1960- 1991
}

\author{
Muhamad Azannudin Mohd Ashari, Khairi Ariffin
}

To Link this Article: http://dx.doi.org/10.6007/IJARBSS/v12-i1/12350

DOI:10.6007/IJARBSS/v12-i1/12350

Received: 15 November 2021, Revised: 21 December 2021, Accepted: 08 January 2022

Published Online: 26 January 2022

In-Text Citation: (Ashari \& Ariffin, 2022)

To Cite this Article: Ashari, M. A. M., \& Ariffin, K. (2022). The Development of Seni Silat Melayu in Kota Bharu, 1960-1991. International Journal of Academic Research in Business and Social Sciences, 12(1), 2708-2717.

Copyright: (c) 2022 The Author(s)

Published by Human Resource Management Academic Research Society (www.hrmars.com)

This article is published under the Creative Commons Attribution (CC BY 4.0) license. Anyone may reproduce, distribute, translate and create derivative works of this article (for both commercial and non0-commercial purposes), subject to full attribution to the original publication and authors. The full terms of this license may be seen

at: http://creativecommons.org/licences/by/4.0/legalcode

Vol. 12, No. 1, 2022, Pg. $2708-2717$

Full Terms \& Conditions of access and use can be found at http://hrmars.com/index.php/pages/detail/publication-ethics 


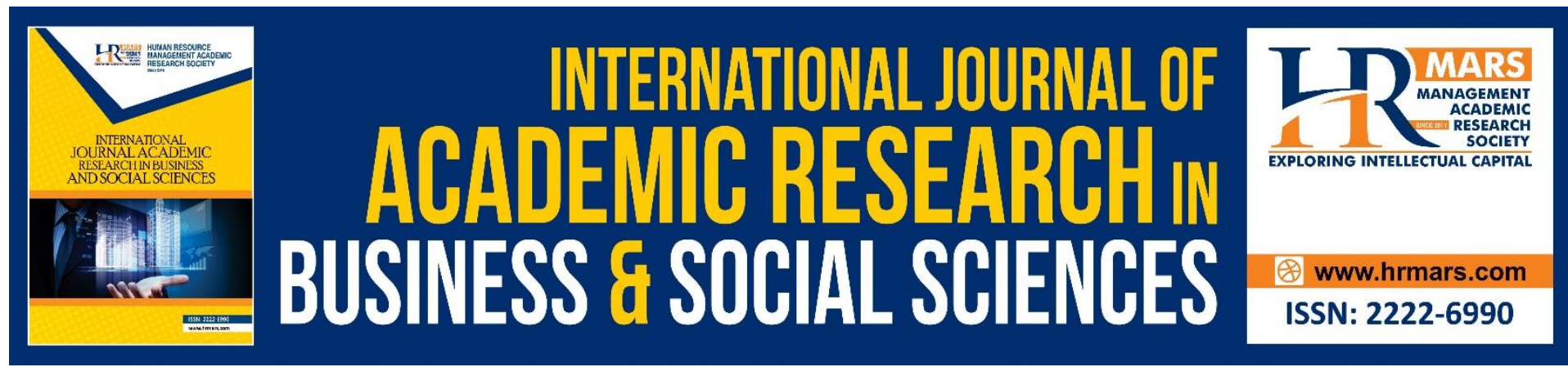

\title{
The Development of Seni Silat Melayu in Kota Bharu, 1960-1991
}

\author{
Muhamad Azannudin Mohd Ashari, Khairi Ariffin \\ Sultan Idris Education University, 35900 Tanjong Malim, Perak
}

\begin{abstract}
This research is to study the development of Malay martial arts Kota Bharu from 1960 to 1991. Many past researchers have researched Silat. However, the research about Silat in Kota Bharu has yet been done. This research was conducted to observe the development of Malay martial arts in a well-known organization, Gayong Fatani Martial Arts Association and Gayuman Segerak Kelantan Martial Arts Association. This research uses a qualitative method by referring to libraries and archives. Primary and secondary sources were used in this research. The primary source refers to document analysis such as annual reports and official organizational files from national archives. Other than that, secondary sources were from national archives, the University of Malaya (UM), Sultan Idris Education University (UPSI) and The National University of Malaysia (UKM). This research finds that every Silat organization based in Kota Bharu has its caterer in spreading knowledge to the community. The development of Malay martial arts can be seen when every instruction has been given the mandate to teach the knowledge gained to the community with the official qualification certificate issued from the Malaysian National Silat Federation (PESAKA). This research finds that Martial Arts Organization in Kota Bharu has changed the community awareness about Malay's traditional martial arts. In the beginning, Malay Martial Art Association uses informal education and a traditional system considered indirect learning. They will carry out lessons in house lawns, sheds and near a 'musolla'. Nevertheless, the martial arts educational system was introduced by using a registered organization that has given a more accepting approach to the local communities to learn this martial art until the addition of Silat rings in Kota Bharu. Keywords: Shed, System, Traditional, Martial Arts, Educational
\end{abstract}

\section{Introduction}

The research of martial art development in Malaya was conducted many times but mainly only in certain states, such as Kedah. However, the researcher conducted a study about the development of the history of Malay martial arts (Gayong Fatani Martial Arts Association and Gayuman Segerak Kelantan Martial Arts Association), which was based in the Kota Bharu district in the year 1960 to 1991 . The teachings of Malay martial arts started to grow in the Kota Bharu district in the year 1970 when locals started to realize the importance of this Malay martial arts after the 13 May 1969 tragedy in Malaya where other forms of martial arts such as Muay Thai starts to take place. In the early establishment, martial arts activities were only conducted in house compounds known as 'Bangsal' (Abidin, 2015). In the early stages, the 
martial arts activities do not have many members. Also, the Malay community's reaction towards the establishment of silat in 1978 was not very good as there were many different teachings and forms of silat. This is because they thought silat was only for show (Mafoot Simon, Muslihat Terselindung Dalam Daya Gerak Silat, Berita Harian). The rising problems were developing and handling these traditional martial arts to expand in the Kota Bharu district by organizing competitions. This situation shows that Silat in the Kota Bharu district has expanded in the local community of Kota Bharu. Apart from that, Silat also spread their influence all over the Malay world, which instils discipline, history and linguistics (Soh, 1991). Martial arts or Silat has been given a unique name in the Malay community, such as Silat Minangkabau, Silat Kurinci, Silat Jawa, Silat Betawi, Silat Lintau and many more according to their predecessors. Generally, when it comes to Malay Silat, it refers to a silat that Malays in Peninsular Malaysia practised.

\section{Background Review}

The background study focuses on Kota Bharu as the main area. Kota Bharu is the capital city in Kelantan and the administrative centre of the state. Kelantan was divided into ten provinces with 65 districts and 445 'mukim'. Seven of the provinces mentioned above are in the northern part of the Kota Bharu state. The people Kelantan or referred to as Kelantanese, according to 1980 's data, around 893,753 people, which is $6.8 \%$ of the Malaysian population. In 1985 , Kelantanese was estimated at around 977,574 , where $92.9 \%$ of them are Malay. The settlements in Kelantan were said has established since 2,000 to 3,000 years BC. As proof, a study conducted by Dr G. DEG Sieveking in 1953 in Cha Cave located at Ninggiri district, Ulu Kelantan, found skeletons, human bones and weapon-like tools. The name of Kelantan was taken by a flash of bright lightning that once struck in Bukit Panau, located in Tanah Merah. This lightning was a guidance system for sailors that wanted to stop near the Kelantan River. Therefore, because of this lightning, the name 'Kilatan' was soon changed to Kelantan. Kelantan is also known as 'Bumi Kelantan', and there were living in this area dated back to 10,000 years ago (Salleh, 1987). Thousands of years ago, Kelantan's name was said to be 'Medang Kamulan'. However, not long after the name was given, it was changed to 'Medang Gana', and this name was used until the fifth century before it was changed again to 'Kelatana' or 'Tanah Kala'. Back then, there was also a Sriwijaya 1 government that was believed situated in Kelantan. This opinion was presented by Dr Mohd Yamin and Dr Amir Hussien and supported by Dr Meons which stated that this Sriwijaya 1 government was located in Kelantan. In Chinese scriptures, the name Kelantan was spelt as 'Ho-lo-tan' or 'Ko' u-lo-tan' used until the second half of the sixth century. According to old history as well, the nickname of the state of Kelantan is mentioned as "Tanah Serendah Sekebun Bunga Cerang Tenggayong or Kisaran Payung". At the end of the sixth century, the name was changed to Raktamrittika, which means Red Soil State. The King of Kelantan named Gautama has given the name after the rebellion of Funan, thus building his capital city deep in the strategic part of the state and has a lot of gold. Kelantan is located on the east coast of peninsular Malaysia between latitude 4 degrees 32 minutes and 6 degrees 15 North (Mahmud, 2005) and longitude 101 degrees 19 and 102 degrees 37 in the East (Mahmud, 1997). To the north, there is the South China Sea, with 60 miles of coastline. The distance from North to South is 118 miles and from East to West is 80 miles. To the West are the states of Perak and Thailand (Salleh, 1985)," where it borders Perak, there is the Banjaran Titiwangsa which also acts as a natural wall between these two states. The two states are now connected by East Coast Highway that spans the range of Banjaran Titiwangsa. Sungai Golok is the divider between Kelantan and Thailand. In 
the South, there is the state of Pahang and in the East is the state of Terengganu. The cultures of Siam influenced Kelantan because the state of Kelantan and Thailand were nearby. This is also due to the political relationships between the two countries once upon a time before.

The area of Kelantan is 14,931 square kilometers (Malek, 1993). The state is divided into ten provinces. The ten provinces are Kota Bharu, Pasir Puteh, Pasir Mas, Bachok, Machang, Tumpat, Tanah Merah, Kuala Krai, Jeli and Gua Musang. The largest district is Gua Musang, with an area of 8,104 square kilometres, while the smallest district is Tumpat district which is only 168 square kilometres. In each province, there is a small administrative unit called a "district". Generally, there are 63 districts throughout the state of Kelantan. Each district is led by a penggawa (formerly Tok Kweng) that is responsible to the province's head, while the combination of provinces forms a state of Kelantan. The state is bordered by four provinces, which is Thailand (Pattani) in the northeast, Perak (Hulu Perak) in the West, Pahang (Kuala Lipis) in the South and Terengganu (Besut) in the east or southeast (Harun, 1999). Kelantan is important cultural dissemination in the Malay peninsula since prehistoric times, Mesolithic and Neolithic. This is because of its strategic geographical position and rich natural resources become the focus of human beings (Salleh, 1980).

\section{Problems Statement}

The community in the Kota Bharu is not interested in sending their children to martial arts classes because they think learning martial arts can damage their children's faith. This situation occurs because of the existence of spiritual elements in learning martial arts, especially Silat. The local community are afraid to venture deeper into the arts of Silat, where they only assumed Silat is only for show and not as a real martial art compared to Muay Thai, boxing and other forms of martial arts. In addition, the community worry that their children will use a weapon while taking martial arts. The clothing needed to learn martial arts at that time is also said to have its function. This situation has indirectly given challenges and problems to the organization in developing martial arts in the district of Kota Bharu.

\section{Methodology}

This study was conducted using qualitative research methods that obtained sources from primary and secondary sources. The primary source obtained by the researcher was by analyzing documents and manuscripts from the organization's files and files obtained from the National Archives of Malaysia and the Kedah and Perlis branch of the National Archives of Malaysia. In addition, secondary sources are also used to support this study by referring to scholarly writings, reference sources available at local universities such as Sultan Idris Education University (UPSI), University of Malaya (UM), The National University of Malaysia (UKM), the National Archives of Malaysia and also the National Archives of Malaysia Kedah and Perlis branch. The resources obtained are valued analytically and interpreted hermeneutically.

\section{Malay Silat Education in Kota Bharu District}

In Kota Bharu, a member of Malay Silat involved can better understand the concept of selflove. This is because all inputs will be rejected or will not penetrate the lust if less suitable methods or approaches are implemented. Applying self-love requires an understanding of the concept of reality and self-resilience (Ismail, 1998). For example, every Silat member must do 
all the practices he is told to do (obey both parents) and abandon all unlawful practices (stealing).

Intense competition from foreign martial arts organizations in Kota Bharu also affects the Malay martial arts development. This can be seen when the founder of Seni Gayung Fatani Association and Silat Gayuman Association tried to show the authentic martial arts that belong to the Malays and are equally great with foreign martial arts such as Siamese Kickboxing, Tae- Kwan Do, Karate, Jujitsu, Aikido, and Kung Fu. However, due to the strong organizational structure and financial position, the greatness of foreign martial arts is highlighted through media promotion and close ties with the ruling community that facilitates the movement of their organizations (Janudin, 1999). From 1960 until 1970, martial arts associations are still driven by old ideologies. The Malay community in the area is less willing to accept changes to their martial arts' organization and management system.

Malay Silat in Kota Bharu is also influenced by the media in the country at that time. They also elevate Malay Silat with classic Malay films acted by Malay actors produced by Jalan Ampas Studio, Show Brothers and Keris Cathay. Among the films are Hang Tuah, Semerah Padi, Pancha Delima, Pendekar Bujang Lapok, Mahsuri, Raja Laksamana Bentan, Megat Terawis, Sultan Mahmud Mangkat Dijulang, Hang Jebat, Seri Mersing, Lanchang Kuning, Cucu Datok Merah and others. It shows that Kelantanese is interested in films that incorporated elements of culture, including Malay Silat and heroism. This can be proved by the existence of cinemas in the city of Kota Bharu in the 1970s. However, foreign cultural elements are still heavily influenced because many of its directors are not from Malaya (Rosin, 2007). Promoting the Malay martial arts in Kota Bharu also received great competition with foreign entertainment media that constantly highlight the superhero familiar with their martial arts as a medium of propaganda of their nation, such as boxing from Thailand, which is a neighbouring country. This is so because the cultural propaganda that was spread aggressively by the Thai army in the southern provinces also affected the Malay states on the East Coast and North West specialized in Kelantan.

However, lessons in Malay Silat have developed as an extra-curricular activity in schools and institutions of higher learning. This can be proven when the Ministry of Education Malaysia held a martial arts competition between secondary schools until the national level started in 1992 (Ismail, 2008). The celebration of the competition with the participation of various martial arts streams is encouraging every year. For example, in the Federal Territory, there are about 58 secondary schools and out of this number, almost 31 schools in the Federal Territory have martial arts associations including Sekolah Menengah Seri Ampang, Sekolah Menengah Saint John, Sekolah Menengah Seri Pantai, Sekolah Menengah Aminuddin Baki and so on. This illustrates that martial arts lessons are still in demand by the younger generation today, and parents and schools also encourage students to venture into the field of martial arts. In Kota Bharu, schools that have martial arts associations are like Sekolah Menengah Kebangsaan Kota Bharu, Sekolah Menengah Kebangsaan Raja Sakti National and so on.

According to the Ministry of Education (MOE) statistics, 11,769 students in 1310 schools across the country joined the Malay silat association. Since the Ministry of Education Malaysia issued its guidelines related to the conditions for establishing martial arts associations in 
schools, schools' involvement in martial arts activities has also increased. Nevertheless, in 1997, that number increased to 600 schools involving 18000 students.

The martial arts activity in the school is said to be a uniformed co-curricular activity recognized by Mr Ayob Ibrahim, School Division Manager, School Department, Ministry of Education. Students who have participated in martial arts no longer need to participate in other uniformed activities, such as Scouts, Red Crescent, Police Cadets and Girl Guides. (Zabidi Hitam, minda pelajar, 10-16 Okt. 2001:3).

\section{Clothings in Silat Seni Melayu in Kota Bharu}

Clothing is one of the critical aspects of martial arts, where it symbolizes heroism and privileges of the Malays. For each martial arts organization in Kota Bharu, the necessary clothing is black where it covers Baju Melayu, or clothes that have been specially created for fighters. In the clothing itself, there are also additional accessories such as sampin, tengkolok, and bengkung. This type of clothing is also said as daily wear for Malays in the Feudal or Sultanate era (Soh, 1991). This can be related due to the heritage of the Malay's predecessors. In addition, the clothing has also modified for war purposes.

\section{Tengkolok}

Tengkolok, also known as Tanjak is a garment worn over a man's head and a symbol of one's heroism. The headgear is made of fabric according to the wearer's wishes, either from songket or ordinary woven fabric worn on the head without stitches. Also, the shape of this hat has its characteristics which also symbolizes a person's status. For example, a King cannot use the same design as an ordinary citizen. This can be seen, the existence of the composition of the hat through the art of folding that has various shapes and names such as seperti Gagak Lapar, Helang Melayang, Siwah Terjun, Helang Patah Sayap, Dendam Tak Sudah, Helang Berlegar, Ayam Patah Kepak, Bulu Ayam, and Pari Mudik. The primary function of this headgear is said to be a protective device to the head, specifically covering the hair of the warrior who is fighting. This is because the use of a tengkolok will not disturb a hero who is fighting. It is said to be very important in the Sultanate since the warriors have long hair.

\section{Shirt and Pants}

The shirts and pants worn by the warriors have certain designs that have their own names such as Baju Cekak Musang, Baju Teluk Belanga, Baju Teluk Belanga, Baju Bujur Sirih, Jerut pants and Tongkah pants. There is a Baju Cekak Musang which has a neck collar. In contrast, the Bujur Sirih shirt has sleeves but no collar but a large $V$ shape. Next, the Tongkah pants are legged pants, and the plate is wide and has a girth more diminutive than the size of a regular sarong. In terms of size, the sleeves and pants of a Malay shirt differ between short and long. Naturally, in the application, there are no rules imposed, but it is up to the users' tastes. There are two main characteristics of a typical Malay shirt in this outfit: the pants sizes are loose and 'pesak'. This shows the use of 'pesak', which is under the armpit, is called a 'kikik', and if the pants have 'pesak', it is called a 'tongkah'. Loose clothing has its purpose, that is so that each pair of martial arts clothing can be worn in turns whether a person's size is large or small. According to the teacher of Seni Silat Tari said that in the organization of seni silat there is not enough money. The next is to avoid being torn when fighting as well as to move freely without interruption. 


\section{Bekung}

Bekung is a type of clothing which is worn at the waist area. A few knots are used, such as 'cindai jantan' and 'cindai betina'. Both of these knots are different as cindai jantan is not as wide as cindai betina. The width is only about the size of a palm and the length about four arms joined together. Besides that, bekung has a protective function that saves the stomach area from any knife penetration. The use of bekung is also to provide extra comfort and tidiness when in battle stances.

\section{Kain Sampin}

Kain sampin is a cloth that is worn around the pants but it is shorter than the pants. The use of sampin can be worn about knee-length, below knee or above the knee. The knot in sampin is regular and artistic. The primary function of sampin is to become a triangle cloth to support a sprained or broken arm. Other than that, sampin is also used as a tool to repel thrown weapons from the enemy (Soh, 1991).

\section{The Development of Seni Silat Gayuman and Gayong Fatani}

One of the Malay martial art organizations that are active is Seni silat Gayuman Segerak Kelantan (PSSGSK) or Gabungan Seni Silat Tari. This organization was introduced by Pak Chu Hussin or Hussain bin Isa bin Mamat in Kota Bharu, and used the registration number PPP/KEL 28/02. He was born on 17 October 1922 in Kampung Sinar Dua, Telipot Kota Bharu Kelantan. He is also the youngest of three siblings. Pak Chu Hussin was very interested in martial arts since he was a child. The first silat to be learned was Gayuman from a man named Tuan Haji Talib or Wak Lid from Kampung Batu Sebutir, Pasir Putih. After that, he learned "Silat buah 7 Hari" and Silat Pulut (dance) while he lived and married in Kampung Binjai. His first wife also learned Gayuman from Wak Lid's student named En. Hassan from Kampung Kangkong, Pasir Mas in Gelanggang near the Telipot ice factory (now Taman Maju).

In 1946 he remarried and settled in Kampung Lundang, Kota Bharu. While in this village, he learned silat with Pak Nik Man, the last court that Pak Nik Man taught. Initially, five trainees were studying, but only five people, including Pak Chu Hussin and Pak Nik Ya. He could not study the entire court because he worked night shifts at the "Lian Tong" Telipot rubber factory despite learning martial arts for six months. Hence, he was only able to study briefly at night after work. Only one entire month he can learn from six months of the lesson. However, he is observant and diligent in learning silat until the end of training or Perlimau in Gelanggang.

Pak Chu Hussin has been invited to be a martial arts teacher because of the blessings of diligence and effort and the natural spirit that is in him and armed with a bit of knowledge. The first court he studied was Dusun Muda Kota Bharu in 1955. From the first court, he continued to teach until the last court in 2002. The spirit of silat in him was solid, making a total of 15 teaching courts. When he was young, if he went to a party where there was a martial arts game, a fever would attack him if he did not fight on that day. This shows that the strength of his martial arts spirit, or called "angin tok dekar". Pak Chu Hussin passed away on the morning of Tuesday 25 Jamadil Akhir 1423 Hijrah equivalent to 3 September 2002 when he was 80 years old. He left a wife and six children with 14 grandchildren. 
Table 1: Gelanggang Silat Pak Chu Hussin (PSSGSK)

\begin{tabular}{|l|l|l|l|}
\hline Number & Start Date & End Date & Place \\
\hline 1 & 1955 & 6 Month & Dusun Muda \\
\hline 2 & 1956 & 6 Month & Dusun Muda \\
\hline 3 & 1958 & 6 Month & Atas Gong, Telipot \\
\hline 4 & 1959 & 6 Month & Atas Gong, Telipot \\
\hline 5 & 1969 & 6 Month & Paya Senang \\
\hline 6 & 1970 & 6 Month & Paya Senang \\
\hline 7 & 1972 & 6 Month & Paya Senang \\
\hline 8 & 1976 & 7 Month & Lundang \\
\hline 9 & 1977 & 10 Month & Lundang \\
\hline 10 & 1978 & 6 Month & Lundang \\
\hline
\end{tabular}

Table 1 shows the opening date of the court by Pak Chu Hussin during his time teaching Seni Silat Gayuman Segerak Kelantan (PSSGSK) in Kota Bharu. In the table, it can be seen that there are ten courts that Pak Chu Hussin has opened in developing the martial arts starting from 1955 to 1978 (Husin, 2012). Pak Chu Hussin's last court was at Lundang Kota Bharu in 2002. From the table, it can be seen that each court will be taught for six months only.

Meanwhile, Seni Gayung Fatani Association Malaysia was established on 20 February 1984, which initially had several members of only ten people. This organization was established in Batu Satu, Pasir Mas Kota Bharu Kelantan by Wan Jaafar bin Wan Zainal, the branch chairman and assisted by Khairuddin bin $\mathrm{Hj}$. Ghazali as the branch secretary using registration number 1886 . Through this organization, some logos and emblems have been used to show that this organization has its own identity: the circle that means unity and cooperation, daggers and shelters that mean sovereignty and peace, and handbooks that mean determination and physical strength. This logo has been officially adopted by the Kelantan branch of Seni Gayung Fatani Association. This organization has a purpose and foundation to unite the fans of Fatani Gayung Art throughout Malaysia. This is because the integrity of unity in ensuring society's well-being is essential because it is the backbone of national security. Next, this organization was also established to safeguard sovereignty and security from anti-national elements. This clearly shows that this organization is indeed having a positive impact on maintaining national security. For example, the Seni Gayung Fatani Association trains spiritually and physically according to the tenets of the nation. Next, the original syllabus or new curriculum is five levels, consisting of fighters who have just entered wearing a white bengkung called Anak Gelanggang and will finish wearing a yellow bengkung at level one as a Pesilat Muda. Next, stage two ends with a green bengkung as a Pesilat. Stage three ended with a red bengkung as a Pendekar Muda. Finally, the fourth level fighters ended up with a black bengkung as a Pendekar. Meanwhile, level five fighters as Pendekar are allowed to follow the Silat coaching course.

Next, membership for Seni Gayung Fatani Association has its own conditions. Among them is that a member must be a Malaysian citizen, male or female, over the age of 7 years and above and have parental permission if aged 18 years or below. As for the committee members, they are appointed through votes by the members of the organisation. Next, to become a valid member, they need to be supported by two other members, and they need 
to make a fee payment. Among the fees charged in 1984 was RM 2.00 and the monthly fee was only RM 0.25 . The monthly fee collected is by the Kelantan branch treasurer. The membership will be cancelled if they do not make a payment three times in a row. The change can be seen when Seni Gayung Fatani Association has sent its members to participate in the national level martial arts tournament.

From the participation, two members got the runner-up and third place at the national level. The competition was in 1984 which was held at the Kg. Pandan, Kuala Lumpur and in 1985 at Tapian court Johor Bharu. This can be seen when martial arts are a competition between two opponents who use one competition court and the existence of rules that have been set. This competition shows that it emphasizes the discipline of wrestlers in practising techniques and tactics in martial arts. Next, Seni Gayung Fatani Association became the focus when a martial arts festival was organized in Kelantan on 2 May 1985, held at the Mini Stadium Pasir Mas. The opening ceremony was conducted by Yang Berhormat Tuan Haji Awang Jabari, the parliamentary secretary of the Ministry of Culture, Youth and Sports Malaysia. A total of 70 members participating in the event. Apart from that, a total of 35 members of Seni Gayung Fatani Association also participated in the demonstration event in conjunction with KDYMM Al-Sultan's birthday. The membership of Seni Gayung Fatani Association in 1976 can be seen in the table below,

Table 2: Total memberships 6 Pertubuhan Seni Gayung Fatani

\begin{tabular}{|l|l|l|l|l|l|}
\hline Gander & Malay & Chinese & Indian & others & Total \\
\hline Male & 306 & - & - & - & 306 \\
\hline Female & 37 & - & - & - & 37 \\
\hline Total & 343 & - & - & - & 343 \\
\hline
\end{tabular}

Based on table 2, 343 members from six Seni Gayung Fatani Association in Kota Bharu. This shows that its membership consists of male citizens with a total of 306 people and 37 women. The Malays have also dominated membership organizations of Seni Gayung Fatani Association. The increasing involvement is due to the change in terms of the learning syllabus, which is to focus on martial arts competitions. This can attract the interest and awareness of the community when they realize that martial arts will benefit them not only physically but also able to become a career. This is proven when Mr. Abdullah bin Muhammad represented the country at the World Athletics Martial Arts Championship from 27 July to 2 August 1986 and took third place. Apart from that, various activities have been organized to attract the community to participate in Silat organizations. Among them is to hold martial arts courses and competitions, which are estimated to cost RM 1459.

\section{Conclusion}

In developing the knowledge of Silat in Kota Bharu, the government has developed several policies to be used as a guide by the newly established Silat organizations to achieve the goals that they created. In addition, several Silat organizations have been established by stages in the district of Kota Bharu to develop the knowledge of Silat.

Moreover, the government can overcome the issues developed when creating a silat organization. Among the problems that arise, there are no qualified teachers to teach in silat. The Silat organization has also set the Silat syllabus to coordinate the effective delivery of 
martial arts in the Kota Bharu based on the needs of co-curricular subjects, especially in schools. Also, the government's efforts in raising awareness of silat are very encouraging when approving silat as an activity that benefits students.

\section{Acknowledgement}

Appreciation to my supervisor, Assosiate Professor Dr Khairi Bin Ariffin for giving me the wonderful opportunity to complete my Master thesis under his supervision, it is truly an honor. Thank you for all advice, ideas, moral support and patience in guiding me through this project.

\section{Corresponding Author}

Muhamad Azannudin bin Mohd Ashari

Sultan Idris Education University, 35900 Tanjong Malim, Perak

Email: azannudin1994@gmail.com

\section{References}

Alexander, H. Chambers, Q, Draeger, D. F. (1970), PENTJAK - SILAT The Indonesian Fighting Art Published by Kodansha International LTD, Tokyo, Japan \& Palo Alto, Calif. U.S.A.

Abidin, M. M. Z. (2015), Aliran Seni Silat Melayu: Perkembangan Pertubuhan Seni Gayung Fatani Malaysia 1976-2008. Latihan IImiah B.A Kuala Lumpur, Universiti Malaya.

Harun, H. (1999), Kelantan Rakyat Dinamik, Negeri Semakin Ketinggalan, Kuala Lumpur, Dd Mediaconsult Sdn. Bhd.

Husin, S. (2012), Dokumentasi sejarah dan aktiviti PSSGSK 1975-2010, Kelantan. Dian Darul Naim Sdn. Bhd. Lundang, Kota Bharu.

Ismail, A. R. (2008), Seni Silat Melayu Sejarah dan Perkembangan dan Budaya, Kuala Lumpur, Dewan Bahasa dan Pustaka.

Ismail, A. M. (1998), Pendekatan IImiah Dalam Seni Silat Cekak". Panglima.

Janudin, S. (1999), Seni Silat Cekak Malaysia Warisan Mutlak Bangsa Melayu. Universiti Sains Malaysia.

Mahmud, A. R. (2005), Ikhtisar sejarah Kelantan, Pustaka Aman Press Sdn. Bhd.

Mahmud, A. R. (1997), Pelajaran Tata Rakyat Negeri Kelantan (1), Kota Bharu: Sofi's Friend \& Book Dealer.

Malek, M. R. (1993), Salasilah Nama Tempat Negeri Kelantan Darul Naim, Petaling Jaya, Prisma Sdn. Bhd.

Rosin, J. (2007), Pengisian Budaya Dalam Filem Melayu. Jurnal Skrin Malaysia.

Salleh, N. M. (1987). "Sistem Politik Dan Kesultanan Kelantan" dalam Zaman Awal: Kajian Arkeologi dan Sejarah di Malaysia, Kota Bharu. Perbadanan Muzium Negeri Kelantan.

Salleh, N. M. (1980)," Salasilah Raja-Raja Kelantan", (Kertas Kerja Seminar Sejarah Dan Budaya Wilayah Kelantan di Kota Bharu pada 12-15 April 1980).

Salleh, M. Z. (1985), “Negeri Kelantan Selayang Pandang”. Fokus Negeri Kelantan. Kota Bharu: Pejabat Setiausaha Kerajaan Kelantan, April 1985.

Suhaimi, N. H. (1986), Kelantan Dalam Perspektif Arkeologi, Kota Bharu: Perbadanan Muzium Negeri Kelantan.

Soh, T. I. T. (1991), Seni Silat Melayu Dengan Tumpuan Kepada Seni Silat Sekebun, Kuala Lumpur. Dewan Bahasa dan Pustaka. 